\title{
Petrogenesis Intrusi Granitoid Langkup di Desa Rantau Kermas dan Sekitarnya, Kecamatan Jangkat, Kabupaten Merangin, Provinsi Jambi
}

\author{
Mulyadi Syaifullah ${ }^{1}$, Hari Wiki Utama ${ }^{1^{*}}$ \\ ${ }^{1}$ Program Studi Teknik Geologi, Fakultas Sains dan Teknologi, Universitas Jambi, Jl. Raya Jambi - Muara Bulian KM.15 Mendalo \\ Indah, Jambi 36361
}

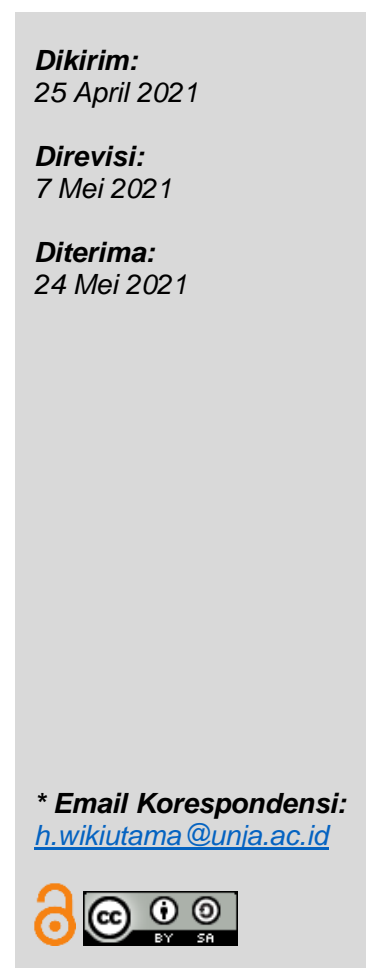

Abstrak: Granitoid Langkup tersingkap baik di Desa Rantau Kermas, dikarenakan keberadaannya tepat tersingkap di bagian Perbukitan Barisan yang merupakan jalur busur magmatik Sunda-Banda berumur Miosen Akhir-Pliosen. Penelitian karakteristik mineralogi Granitoid Langkup menjadi penting dan menarik untuk dapat menjelaskan pembentukan batuan, dengan menggunakan analisis petrografi sehingga hasilnya dapat memberikan gambaran mengenai tipe Granitoid yang terdapat di Formasi Langkup, hubungan antara kegiatan magmatisme, serta keberadaan sumberdaya mineral dan energi. Pada metode penelitian tahap awal dilakukan pengamatan Citra Model Elevasi Digital (DEM) dengan menggunakan perangkat lunak Arcgis 10.5.1 format UTM dengan skala peta 1:25.000. Tahap selanjutnya berupa survey di lapangan dengan pengamatan geomorfologi, pengamatan singkapan, pengukuran struktur geologi, dan stratigrafi terukur. Untuk mengetahui karakteristik batuan, serta tipe Granitod dilakukan analisis petrografi pada sampel batuan dengan klasifikasi batuan beku IUGS. Magma yang mengandung unsur gas dan bersifat bergerak (mobile) dengan temperatur tinggi dan tekanan yang tinggi bergerak menuju tekanan yang lebih rendah. Pergerakan magma yang menerobos naik dipengaruhi oleh pengangkatan dan struktur geologi berupa sesar yang menyebabkan terbentuknya intrusi batuan. Pada saat magma naik menginjeksi batuan samping terjadi proses silisifikasi yang mengakibatkan peningkatan derajat keasaman magma membentuk batuan granit. Pengelompokan tipe granitoid berdasarkan asal usul pembentukkan granit, granitoid di daerah penelitian termasuk granitoid tipe-l, yaitu granitoid yang terbentuk dari diferensiasi batuan beku. Hal ini dibuktikan dengan adanya mineral penciri seperti kehadiran hornblenda dan biotit. Batuan granit yang berada pada daerah penelitian dapat diinterpretasikan terbentuk pada lingkungan tektonik zona konvergen yakni pada zona tepian benua aktif (Active Continental Margin).

Kata kunci: Granitoid Langkup, magmatisme, petrogenesis.

\begin{abstract}
The Langkup Granitoid is well exposed in the village of Rantau Kermas, because its existence is precisely exposed in the Barisan Hills section, which is the Sund-Banda magmatic arc pathway of the late MiocenePliocene age. Research on the mineralogical characteristics of the Langkup Granitoid is important and interesting in order to explain rock formation, using petrographic analysis so that the results can provide an overview of the Granitoid type found in the Langkup Formation, the relationship between magmatism and the presence of mineral and energy resources. In the initial research method, the Digital Elevation Model Image (DEM) was observed using Arcgis 10.5.1 UTM format software with a map scale of 1:25,000. The next stage is a survey in the field with geomorphological observations, outcrop observations, geological structure measurements, and measured stratigraphy. To determine the rock characteristics, as well as the Granitod type, petrographic analysis was carried out on rock samples with the IUGS igneous rock classification. Magma which contains gaseous elements and is mobile with high temperature and high pressure moves towards a lower pressure. The movement of magma that breaks up is influenced by uplift and geological structures in the form of faults that cause rock intrusions to form. When the magma rises to inject the side rocks, a silicification process occurs which results in an increase in the acidity of the magma to form granite rocks. The grouping of granitoid types is based on the origin of granite formation. Granitoids in the study area are including type - I granitoids, namely granitoids formed from igneous rock differentiation. This is evidenced by the presence of characteristic minerals such as the presence of hornblende and biotite. The granite rocks in the study area can be interpreted as being formed in the tectonic environment of the convergent zone, namely the Active Continental Margin Zone.

Keywords: Langkup Granitoid, magmatism, petrogenesis.
\end{abstract}

\section{PENDAHULUAN}

Busur magmatik Sunda-Banda adalah hasil dari sejarah kompleks dan proses tektonik Pulau Sumatra, yang mengakibatkan terjadinya subduksi, magmatisme busur, migrasi busur, rotasi, penyebaran busur belakang, sesar mendatar, dan ekstensi kerak (Metcalfe, 2017, 2013a, 2013b, 2011; Carlile \& Mitchell, 1994). Granitoid Langkup merupakan intrusi Tersier Pliosen, yang termasuk dalam Zona Perbukitan Barisan. Intrusi tersebut merupakan bagian dari busur magmatik muda yang tersingkap di Pulau Sumatra (Advokaat dkk., 2018; Kusnama dkk., 1992; van Bemmelen, 1949). Untuk memahami bagaimana karakteristik Granitoid Langkup, sehingga memerlukan pemahaman tentang petrogenesis batuan tersebut.

Granitoid Langkup tersingkap baik di Desa Rantau Kermas, dikarenakan keberadaannya tepat tersingkap di bagian Perbukitan Barisan yang merupakan jalur busur magmatik Sunda-Banda DOI: https://doi.org/10.23960/igrs.2021.v2i1.59 
berumur Miosen Akhir-Pliosen (Maryono dkk., 2014; Prasetyadi dkk., 2016; Poedjoprajitno, 2012). Penelitian karakteristik mineralogi Granitoid Langkup menjadi penting dan menarik untuk dapat menjelaskan pembentukan batuan, dengan menggunakan analisis petrografi sehingga hasilnya dapat memberikan gambaran mengenai tipe Granitoid Langkup, hubungan antara kegiatan magmatisme dan keberadaan sumberdaya mineral.

Pembentukkan batuan akan memperlihatkan komposisi kimia maupun kandungan mineral yang berbeda antara satu fase dengan fase lainnya, hal ini dikarenakan adanya perubahan magma dari fase cair ke fase padat yang dikontrol oleh perubahan temperatur dan tekanan dalam proses kristalisasi (Lange dkk., 2018; Gill, 2010; Clarke \& Stephens, 1992).

\section{KONDISI GEOLOGI REGIONAL}

Berdasarkan klasifikasi van Bemmelen (1949), Pulau Sumatra ini dibagi menjadi enam zona fisiografi yaitu Zona Pegunungan Barisan, Zona Sesar Semangko, Zona Pegunungan Tigapuluh, Zona Dataran Rendah dan Dataran Bergelombang, Zona Paparan Sunda, dan Zona Kepulauan Busur Luar.

\subsection{Tatanan Tektonik}

Sumatra terletak di barat daya dari Kontinen Sundaland dan merupakan jalur konvergensi antara Lempeng Hindia-Australia yang menyusup di sebelah barat Lempeng Eurasia (Lange dkk., 2018; Metcalfe, 2017). Akibat dari konvergensi lempeng menghasilkan tatanan tektonik yang cukup kompleks pada pembentukan Pulau Sumatra (Gambar 1). Berdasarkan hal ini, terdapat beberapa fase tektonik sebagai berikut.

- Permian Akhir. Pada fase ini terjadi kolisi antara blok Sibumasu dan Malaya Timur dari Indochina bersamaan dengan pembentukan batuan dasar.

- Trias-Jura. Pada fase ini terjadi kegiatan tektonik berupa transcurrent system (sesar mendatar) antara blok Sibumasu dan blok Sumatra Barat.

- Akhir Kapur. Pada fase ini juga terjadi obduksi tektonik antara blok Sumatra Barat dan blok Woyla yang menyebabkan terbentuknya sesarsesar naik.

- Pada Paleogen-Neogen, terjadi magmatismevulkanisme yang menjadi alasan terbentuknya Formasi Nagan, Formasi Bandan, dan Formasi Granitoid Langkup yang merupakan intrusi muda dari Neogen. Pada Oligosen-Miosen, Pulau Sumatra mengalami rotasi yang mengalihkan dari pure shear menjadi simple shear.

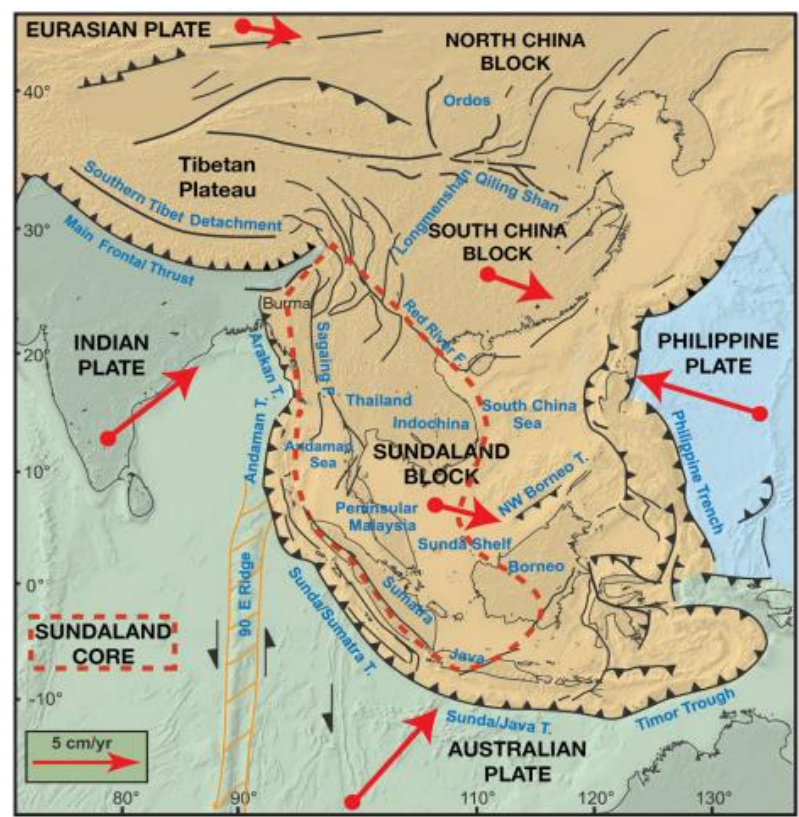

Gambar 1. Latar tektonik Sumatra dengan dasar Samudera Hindia subduksi di bawah barat daya margin dari Sundaland (Metcalfe, 2017).

\subsection{Stratigrafi}

Secara stratigrafi daerah penelitian berdasarkan Peta Geologi Lembar Sungaipenuh dan Ketaun (Kusnama dkk., 1992). Pada daerah penelitian satuan batuan dapat dibedakan menjadi empat yaitu Lava Andesit Hulusimpang, Breksi Andesit Hulusimpang (Tmoh) berumur Oligosen-Miosen, Intrusi Granitoid langkup (Tpdgl) berumur Paleosen-Plistosen, dan Breksi Vulkanik Kuarter (Qtv) berumur Plistosen.

\subsection{Struktur Geologi}

Sesar Sumatra tersebut terdiri dari beberapa segmen yang tidak menerus. Di sepanjang Bukit Barisan ditemukan perisai-perisai yang di atasnya terletak sejumlah besar graben-graben (Natawidjaja, 2018; Hartono \& Sulistyawan, 2011; Permana dkk., 2010). Graben-graben yang terletak

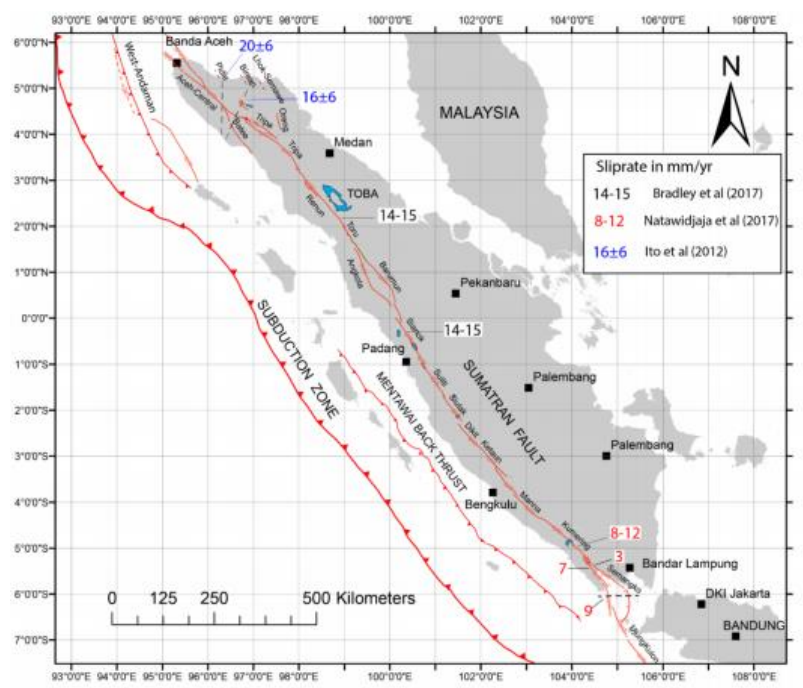

Gambar 2. Segmen Utama Sesar Sumatra (Natawidjaja, 2018). 
di atas kulminasi Bukit barisan ini pada umumnya berbentuk tidak memanjang, akan tetapi berupa persegi empat. Hal ini disebabkan karena bentuk memanjang dari graben itu telah diganggu oleh aktivitas vulkanik yang kemudian membentuk cekungan vulkano-tektonik. Zona patahan Sumatra mengandung batuan-batuan vulkanik asam, aliran tufa pasir dan tuf berbatuapung. Hal ini disebabkan patahan-patahan ini terletak di daerah orogen dan besar kemungkinan batuan asam lelehan ini bersumber dari batu granit yang terletak di bawahnya (Natawidjaja, 2018; Daryono dkk., 2012;
Barber dkk., 2005) membagi sesar Sumatra ini menjadi 19 segmen utama (Gambar 2).

\section{BAHAN DAN METODE PENELITIAN}

Daerah penelitian secara geografis terletak pada koordinat UTM (Universal Tranvers Mercator) $8064000 \mathrm{mT}$ - $8104000 \mathrm{mT}$ dan $9709000 \mathrm{mU}$ $9715000 \mathrm{mU}$ Zona 47S. Sementara secara administratif, daerah penelitian ini termasuk ke Kecamatan Jangkat, Kabupaten Merangin, Provinsi Jambi. Luas daerah penelitian ini adalah sekitar 30 $\mathrm{km}^{2}$.

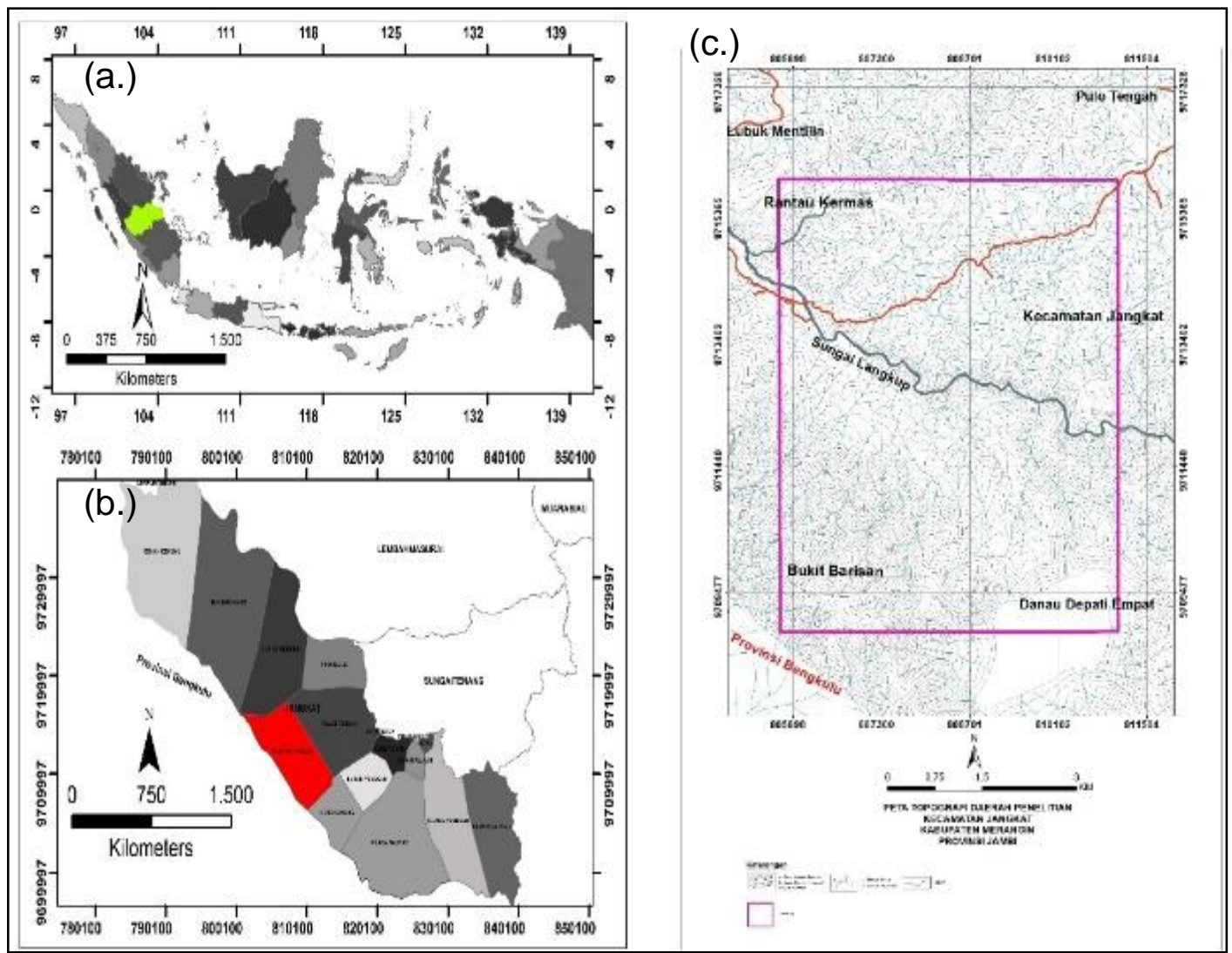

Gambar 3. Peta Daerah Penelitian (a. Peta Provinsi Indonesia, b. Peta administrasi Kecamatan Jangkat, c. Peta Topografi daerah Penelitian).

Untuk mencapai daerah penelitian memerlukan waktu \pm 6 jam dengan menggunakan mobil ataupun motor dari Kota Jambi dan dari Kota Bangko menuju Kecamatan Jangkat, Desa Rantau Kermas memerlukan waktu perjalanan sekitar \pm 4 jam (Gambar 3).

Tahap awal merupakan pengamatan Citra Model Elevasi Digital (DEM) dengan melakukan analisis penginderaan jauh untuk mengetahui kelurusan-kelurusan pegunungan maupun lembahlembah untuk dapat membantu dalam menganalisis daerah yang terdapat struktur. Arcgis 10.5.1 merupakan perangkat lunak pengolahan peta dasar yang menggunakan format UTM dengan skala peta 1:25.000. Peta dasar ini terdiri dari data kontur, interval ketinggian, nama dan wilayah daerah administrasi, sungai dan infrastruktur berupa jalan, yang berfungsi dalam orientasi medan dan analisis kondisi geologi.
Tahap pemetaan geologi lapangan merupakan kegiatan pengambilan data survei keadaan kondisi geologi sampai menyajikannya menjadi geoinformasi. Tahapan di lapangan yang dilakukan adalah pengamatan geomorfologi, pengamatan singkapan, pengukuran struktur geologi, dan stratigrafi terukur.

Dalam tahap preparasi sampel yang dilakukan adalah memisahkan sampel batuan yang akan digunakan dalam analisis petrografi. Pada analisis petrografi yang digunakan adalah sampel batuan segar. Analisis petrografi ini dilakukan untuk mengetahui komposisi mineral penyusun batuan.

\section{HASIL DAN PEMBAHASAN \\ 4.1 Morfologi Daerah Penelitian}

Pola pengaliran yang terbentuk pada daerah penelitian merupakan pola pengaliran Rectangular, Trellis, Parallel, Radial Sentripetal, dan Radial Sentrifugal dengan lembah-lembah sungai DOI: https://doi.org/10.23960/jgrs.2021.v2i1.59 
berbentuk "V" yang dikendalikan oleh struktur regional. Hal ini menandakan bahwa pada daerah penelitian merupakan daerah dengan sungai stadia muda dengan kondisi sungai mengalir diatas batuan dasar (bedrock stream) sebagai buktinya pada daerah penelitian yaitu pada Sungai Langkup.

Bentukan asal pada daerah penelitian berdasarkan modifikasi dari klasifikasi Vertstappen (1985). Berdasarkan letak geografis, daerah penelitian dapat diklasifikasikan sebagai Zona Perbukitan Barisan. Kenampakan morfologi daerah peneltian umumnya merupakan perbukitan, lembah dan dataran. daerah penelitian Desa Rantau Kermas dan sekitarnya memiliki bentukan asal vulkanik pengelompokan satuan geomorfologi daerah penelitian berdasarkan interpretasi awal pada peta geomorfologi tentatif dan di kombinasikan dengan kenampakan morfologi dan data di lapangan. Geomorfologi daerah penelitian di kegolongkan ke dalam 4 satuan Bentuklahan, yaitu Satuan Bentuklahan Perbuktian vulkanik Structural, Satuan Bentuklahan Perbukitan Vulkanik, Tubuh Intrusi, dan Satuan Bentuklahan Danau Tektonik.

\subsection{Stratigrafi Daerah Penelitian}

Stratigrafi daerah penelitian dapat dilihat pada gambar tabel (Gambar 4). Pada satuan batuan daerah peneltian dapat dibedakan menjadi empat yaitu Lava Vulkanik Hulusimpang, Breksi Vulkanik Hulusimpang (Tmoh) berumur Oligosen-Miosen, Intrusi Granitoid langkup (Tpdgl) berumur Paleosen-Plistosen, dan Breksi Vulkanik Kuarter (QTv) berumur Plistosen (Lampiran Gambar 1).

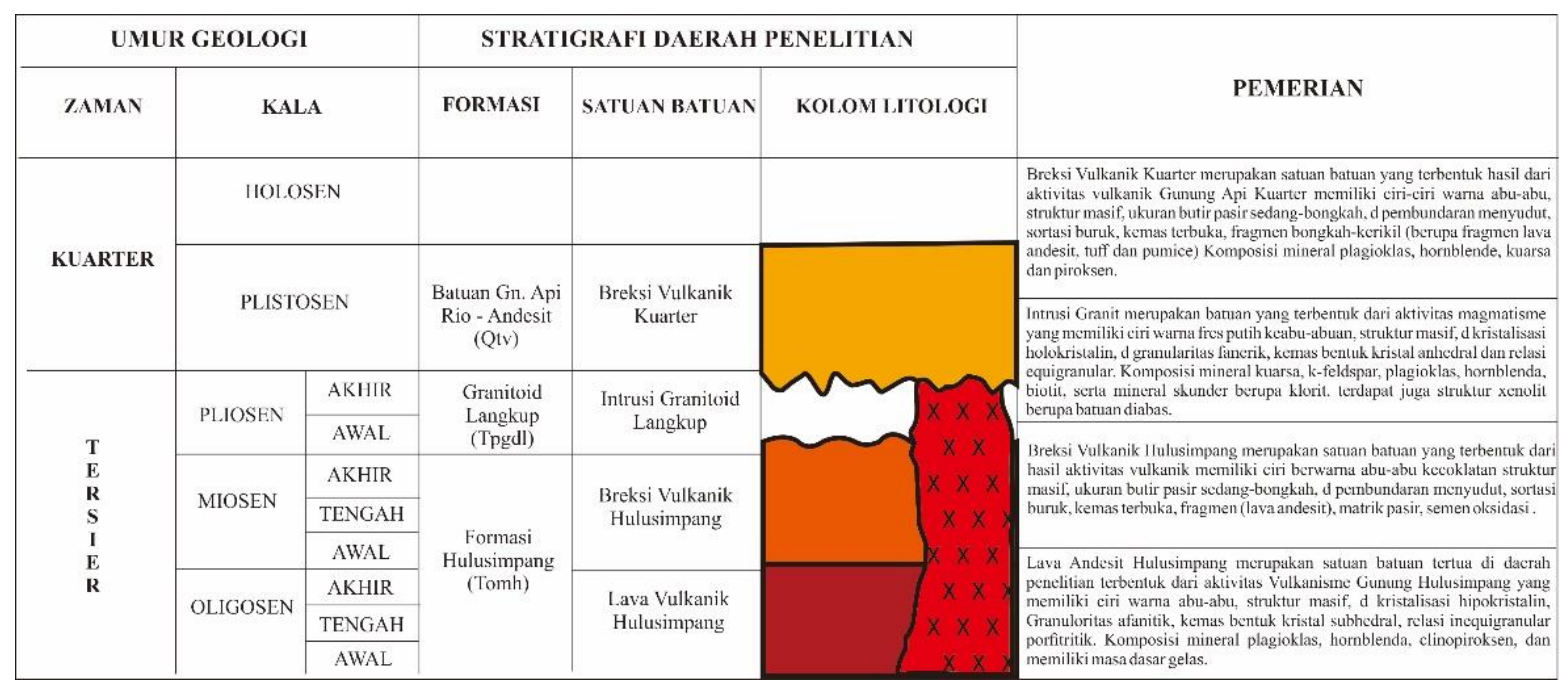

Gambar 4. Kolom Stratigrafi Daerah Penelitian.

\subsection{Struktur Geologi}

Analisis struktur geologi pada daerah penelitian berdasarkan indikasi struktur yang ditemukan di lapangan seperti pengukuran data sesar. Selain itu juga didukung dengan analisa pola kelurusan pada pegunungan dan lembah. Struktur sesar yang ditemukan pada daerah penelitian merupakan sesar regional yaitu Sesar Sumatra berupa segmen Sesar Dikit. Struktur Segmen Sesar Dikit terbentuk akibat proses tektonik yang terdapat pada daerah penelitian, hal tersebut dapat dilihat pada hasil analisis struktur.

Berdasarkan data hasil pengukuran struktur pada daerah penelitian terdapat struktur sesar yang ditemukan di Sungai Langkup. Struktur sesar yang berperan aktif pada daerah penelitian berarah barat laut-tenggara dan menunjukan sesar mendatar kanan. Struktur yang terdapat pada daerah penelitian tersebut berperan penting dalam proses tersingkapnya intrusi Granitoid di Sungai Langkup dan sekitarnya. Struktur yang terjadi menyebabkan aktifitas jalur-jalur busur magmatisme muda, antara lain busur magmatisme Granitoid Langkup menerobos satuan-satuan ataupun litologi di bawahnya, yaitu litologi lava dan breksi vulkanik Hulusimpang. (Gambar 6).

ISSN 2722-3647

ISSN 2722-3639 (e)

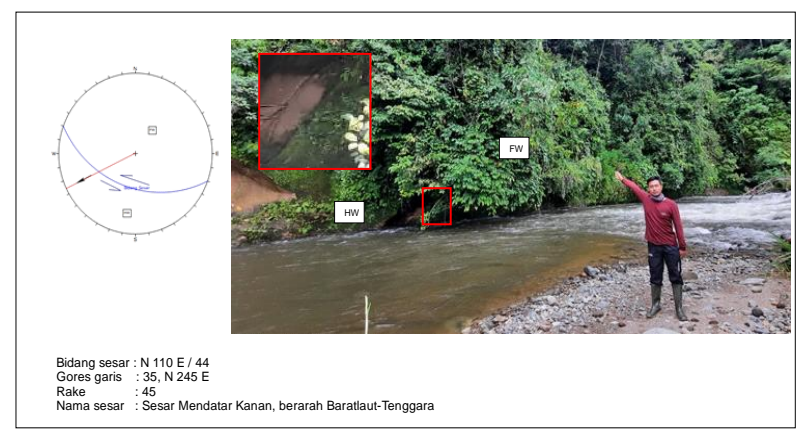

Gambar 6. Struktur Sesar Daerah Penelitian.

\subsection{Analisa Petrografi}

Berdasarkan hasil analisis petrografi pada sampel setangan yang telah diambil di lapangan, menunjukan jenis granitoid yaitu kelompok granit. Pengelompokan tersebut selaras dengan hasil pengamatan megaskopis di lapangan. Pada sayatan tipis dengan memiliki ukuran kristal 0-2 $\mathrm{mm}$, memiliki batas kristal anhedral, dengan tekstur fenerik. Komposisi mineral yang terdapat pada batuan terdiri dari mineral kuarsa, ortoklas, plagioklas, hornblenda, sedikit mineral biotit dan 
mineral skunder berupa klorit. Berdasarkan normalisasi terhadap persentase kuarsa, alkalin feldspar dan plagioklas dengan klasifikasi batuan beku IUGS, granitoid yang terdapat pada daerah penelitian Desa Rantau Kermas dan sekitarnya merupakan batuan granit.

Pada petrografi jenis Granitoid yang pertama, memiliki warna abu-abu gelap (XPL), warna putih cerah (PPL), tekstur anhedral, fenerik, holokristalin. Komposisi mineral pada sampel batuan tersebut umumnya terdiri atas kuarsa $25 \%$, plagioklas $25 \%$, orthoklas $30 \%$, hornblenda $7 \%$, biotit $5 \%$, opaq $3 \%$ dan terdapat mineral ubahan berupa klorit 5\%. Dari hasil kandungan mineral yang terdapat pada batuan, sesuai dengan klasifikasi IUGS (Streckeisen, 2002) granitoid ini memiliki nama petrografi granit.

Pada petrografi jenis Granitoid yang kedua, memiliki warna abu-abu gelap (XPL), warna putih cerah (PPL), tekstur Subhedral-euhedral, fenerik, holokristalin. Komposisi mineral pada sampel batuan tersebut umumnya terdiri atas kuarsa $20 \%$, plagioklas 25\%, Orthoklas 35\%, hornblende 10\%, biotit $8 \%$ dan opaq 3\%. Dari hasil kandungan mineral yang terdapat pada batuan, sesuai dengan klasifikasi IUGS (Streckeisen, 2002) granitoid ini memiliki nama petrografi granit.

\subsection{Diferensiasi Magma Pembentukan Granitoid}

Diferensiasi magma yang terjadi pada dapur magma waktu ke waktu menyebabkan perubahan komposisi pada magma sehingga produk yang dihasilkan berbeda. Sampel yang diambil pada daerah penelitian berdasarkan analisis petrologi dan petrografi memiliki jenis komposisi mineral yang berbeda-beda. Diferensiasi magma menyebabkan magma pada reservoar terbagi berdasarkan kristalisasi mineral. Fase yang pertama terjadi yaitu fase kristalisasi fraksional, yaitu terbentuknya mineral penyusun batuan seperti plagioklas. Terjadi penurunan temperatur dan membentuk pertumbuhan mineral feldspar yaitu orthoklas, hornblenda dan mineral kuarsa serta mineral ubahan berupa klorit. Pada saat magma naik terjadi asimilasi magma dengan batuan samping yang mengakibatkan peningkatan derajat keasaman magma membentuk batuan granit.

\subsection{Petrogenesis Granitoid Daerah Penelitian}

Intrusi Granitoid Langkup secara morfologi merupakan punggungan yang membentukan pola kelurusan, yang keberadaannya tepat di bawah Perbukitan Barisan yang dibatasi oleh Sungai Langkup. Pada daerah penelitian keberadaan Intrusi Granitoid Langkup berada pada barat lauttenggara dengan pola pengaliran yang berkembang yaitu rektangular dan paralel yang dipengaruhi oleh struktur geologi. Bentuk lembah V dan memiliki kerapatan kontur rapat dengan elevasi 900-1300 mdpl. Secara morfogenesa litologi batuan merupakan hasil dari proses magmatisme dan pengangkatan yang dipengaruhi oleh struktur geologi.
Pembentukan batuan granitoid pada daerah penelitian ada beberapa fase pembentukannya yaitu pada Zaman Trias-Jura Awal blok Sumatra Barat dan Samudera Hindia mengalami konvergen yang mengakibatkan proses magmatisme. Bertemu atau menyusupnya lempeng Samudera Hindia ini menjadikan temperatur yang sangat tinggi sehingga melelehkan material-material dalam kerak samudera dan kerak benua menjadi magma pijar yang bersifat bergerak. Pada zaman Paleogen terjadi subduksi yang menyebabkan terbentuknya busur vulkanik Oligosen-Miosen diantaranya, busur vulkanik Formasi Hulusimpang. Aktifitas subduksi kembali pada Zaman Pliosen Akhir, menyebabkan terjadinya jalur-jalur magmatisme muda diantaranya jalur busur magmatisme Granit Langkup yang menorobos satuan-satuan litologi dibawahnya yaitu breksi dan lava andesit Hulusimpang.

Magma yang mengandung unsur gas dan bersifat bergerak (mobile) dengan temperatur tinggi dan tekanan yang tinggi bergerak menuju tekanan yang lebih rendah. Proses magmatisme yang terjadi pada daerah penelitian merupakan diferensiasi magma dan asimilasi magma. Fase kristalisasi merupakan proses sepanjang diferensiasi magma, pada fase ini terbentuk unsur-unsur penyusun batuan seperti mineral plagioklas yang dominan hadir. Penurunan temperatur yang menyebabkan hadirnya mineral k-feldspar dan mineral kuarsa. Pada saat magma naik menginjeksi batuan samping terjadi proses silisifikasi yang mengakibatkan peningkatan derajat keasaman magma membentuk batuan granit.

Tabel 1. Karakteristik Tipe Pembentukan Granit (Modifikasi dari Irzon, 2015).

\begin{tabular}{|c|c|c|}
\hline No. & $\begin{array}{c}\text { Tipe } \\
\text { Granit }\end{array}$ & Karakteristik \\
\hline 1. & $\begin{array}{l}\text { Granit } \\
\text { Tipe-I }\end{array}$ & $\begin{array}{lcr}\begin{array}{l}\text { Terbentuk } \\
\text { diferensiasi } \\
\text { (igneous) }\end{array} & \begin{array}{c}\text { akibat } \\
\text { batuaan }\end{array} & \begin{array}{r}\text { dari } \\
\text { beku }\end{array} \\
& & \end{array}$ \\
\hline 2. & $\begin{array}{l}\text { Granit } \\
\text { Tipe-S }\end{array}$ & $\begin{array}{l}\text { Sebagai hasil dari proses ultra- } \\
\text { metamorfosis batuan sedimen } \\
\text { (sedimentary) }\end{array}$ \\
\hline 3. & $\begin{array}{l}\text { Granit } \\
\text { Tipe-A }\end{array}$ & $\begin{array}{l}\text { Terbentuk karena tatanan } \\
\text { tektonik (tectonic setting) pada } \\
\text { wilayah anorogenik yang tidak } \\
\text { terkait dengan tumbukan } \\
\text { lempeng }\end{array}$ \\
\hline 4. & $\begin{array}{l}\text { Granit } \\
\text { Tipe-M }\end{array}$ & $\begin{array}{l}\text { Terbentuk dari proses peleburan } \\
\text { pada mantel bumi. Tipe-M dan } \\
\text { Tipe-A tidak banyak ada dan } \\
\text { tidak berperan dalam } \\
\text { pembentukan lempeng benua }\end{array}$ \\
\hline 5. & $\begin{array}{l}\text { Granit } \\
\text { Tipe-C }\end{array}$ & $\begin{array}{l}\text { Merupaksn golongan } \\
\text { Charnockitic Granitoid. Namun, } \\
\text { masih menjadi perdebatan } \\
\text { karena tipe ini dapat dijumpai } \\
\text { pada batuan vulkanik maupun } \\
\text { plutonik. }\end{array}$ \\
\hline
\end{tabular}


Pengelompokan tipe granitoid berdasarkan asal usul pembentukkan granit, granitoid di daerah penelitian termasuk granitoid tipe-I, yaitu granitoid yang terbentuk dari diferensiasi batuan beku. Hal ini dibuktikan dengan adanya mineral penciri seperti kehadiran hornblenda dan biotit. Batuan granit yang berada pada daerah penelitian dapat diinterpretasikan terbentuk pada lingkungan tektonik zona konvergen yakni pada zona tepian benua aktif (Active Continental Margin). Granitoid tipe-I dapat berasosiasi menghasilkan potensi sumber daya bahan galian berupa tembaga $(\mathrm{Cu})$, timbal $(\mathrm{Pb})$, seng $(\mathrm{Zn})$, molibden (Mo), wolfram (W), perak $(\mathrm{Ag})$, emas $(\mathrm{Au})$ dan besi $(\mathrm{Fe})$.

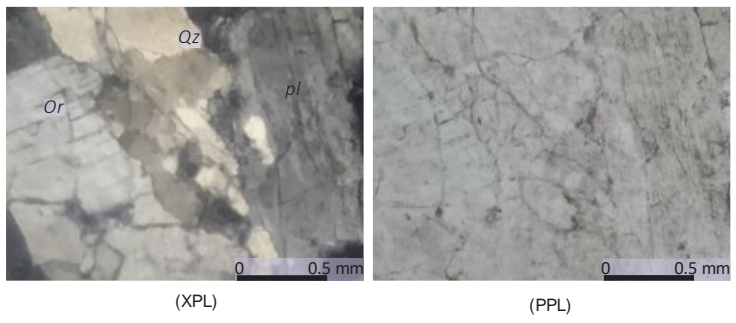

Gambar 7. Sayatan Petrografi Nikol Silang (XPL) (a) dan Sayatan Petrografi Nikol Sejajar (PPL) (b) yang terdiri atas mineral plagioklas, kuarsa, kfeldspar.

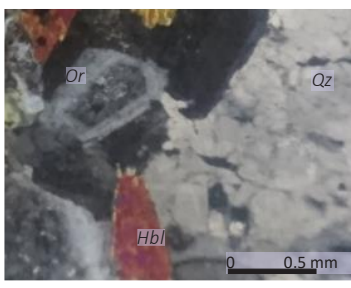

(XPL)

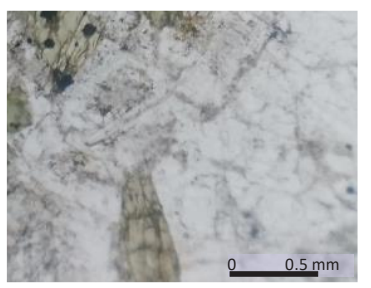

(PPL)
Gambar 8. Sayatan Petrografi Nikol Silang (XPL) (a) dan Sayatan Petrografi Nikol Sejajar (PPL) (b) yang terdiri atas mineral plagioklas, kuarsa, hornblende, k-feldspar.

\section{KESIMPULAN}

Dari hasil penelitian yang telah dilaksanakan, maka dapat disimpulkan bahwa karakteristik granitoid pada daerah penelitian berdasarkan analisa petrografi termasuk ke dalam intrusi batuan beku granit menurut klasifikasi IUGS. Tipe granitoid pada daerah penelitian berdasarkan asal usul pembentukannya, termasuk granitoid tipe-I, yaitu granitoid yang terbentuk dari diferensiasi batuan beku. Hal ini dibuktikan dengan adanya mineral penciri seperti kehadiran hornblenda dan biotit. Batuan granit yang berada pada daerah penelitian dapat diinterpretasikan terbentuk pada lingkungan tektonik zona konvergen yakni pada zona tepian benua aktif (Active Continental Margin).

\section{UCAPAN TERIMA KASIH}

Alhamdulillahhirabbil'alamin, puji syukur kehadirat Allah SWT yang telah melimpahkan rahmat dan hidayah-Nya. Shalawat dan salam sampaikan kepada junjungan Nabi Muhammad SAW selaku uswatun hasanah bagi umat yang senantiasa mengaharapkan syafa'atnya di dunia dan di akhirat.

Terimakasih kepada kedua orang tua yang selalu memberikan do'a dan dukungan, serta dosen Program Studi teknik Geologi Universitas Jambi terutama kepada bapak Ir. Arsyad Ar, M.S. selaku pembingan utama dan bapak Hari Wiki Utama, S.T., M.Eng selaku pembimbing pendamping.

\section{DAFTAR PUSTAKA}

Advokaat, E. L., Bonger, M. L. M., Rudyawan, A., BouDagher-Fadhel, M. K., Langereis, C. G., \& van Hinsbergen, D. J. J. (2018). Early Cretaceous origin of the Woyla Arc, Sumatra, Indonesia on the Australian plate. Earth and Planetary Science Letters, 498, 348-361.

Barber, A. J., Crow, M. J., \& Milsom, J. S. (2005). Sumatra: Geology, Resources, and Tectonic Evolution. London, Geological Society hal. 290.

Carlile J.C., \& Mitchell, A. H. G. (1994). Magmatics arc and associated gold and copper mineralization in Indonesia. In Journal of Geochemical Exploration, (50), 91-142.

Clarke, M.C.G., \& Stephens, B. B. (1992). Geochemistry, Mineralogy and Plate Tectonic Setting of a Late Creataceous Sn-W Granite from Sumatra, Indonesia. Mineralogy Magazine, UK, (10), 369.

Daryono, M. R., Natawidjaja, D. H., \& Sieh, K. (2012). Twin-surface ruptures of the March 2007>6 earthquake doublet on the Sumatran fault. Bulletin of The Seismological Society of America, 102(6), 2356-2367.

Gill, R. (2010). Igneous Rock and Processes: A Practical Guide. Wiley-Blackwell, Wes Sussex.

Hartono, U., \& Sulistyawan, R. I. H. (2011). An overview of arc magma petrogenesis. J. of Geological Resources, 21(4), 179-190.

Irzon, R. (2015). Genesis Granit Muncung dari Pulau Lingga Berdasarkan Data Geokimia dan Mikroskopis. Jurnal Geologi dan Sumberdaya Mineral, 3,141-149.

Kusnama, Pardede, R., Mangga, S. A., \& Sidarto, (1992). Peta Geologi Lembar Sungaipenuh and Ketahun, Sumatra Skala 1: 250.000. Pusat Penelitian dan Pengembangan Geologi, Bandung.

Lange, D., Tilman, F., Henstock, T., Rietbrock, A., Natawidjaja, D. H., \& Kopp, H. (2018). Structure of the central Sumatran subduction zone revealed by local earthquake travel-time tomography using an amphibious network. Solid Earth, 9, 1035-1049.

Maryono, A., Setijadji, L. D., Arif, J., Harrison, R. L., Soeriaatmadja, E., Daya, B.S., Sawit, B.D., \& Timur, J. (2014). Gold, Silver, and Copper Metallogeny of the Eastern Sunda Magmatic Arc Indonesia Metalogeni Emas, Perak , dan Tembaga Busur Sunda Bagian Timur, Indonesia. Majalah Geologi Indonesia, 29(2), 5-99. 
Metcalfe, I., (2011). Tectonic framework and Phanerozoic evolution of Sundaland. Gondwana Research, 19, 3-21.

Metcalfe, I., 2013a. Gondwana dispersion and Asian accretion: Tectonic and palaeogeographic evolution of eastern Tethys. Journal of Asian Earth Sciences, 66, 1-33.

Metcalfe, I., 2013b. Tectonic Evolution of the Malaya Peninsula. Journal of Asian Earth Sciences, 76, 195-213.

Metcalfe, I., (2017). Tectonic Evolutions of Sundaland. Bulletin of the Geological Society of Malaysia, 63, 27-60.

Permana, H., Handayani, L., Gaffar, E. Z. (2010). Studi Awal Pola Struktur Bususr Muka Aceh, Sumatra Bagian Utara (Indonesia): Penafsiran dan Analisis Peta Batimetri. Jurnal Geologi Kelautan, 8(3), 105-118.

Natawidjaja, D. H. (2018). Updating active fault maps and sliprates along the Sumatran fault zone Indonesia. IOP Conf. Series: Earth and Environmental Science, 118012001.

Poedjoprajitno, S. (2012). Morphotectonic and Natural Hazard Potential In The Kerinci Valley West Sumatra, Based On Aerial Photograph Interpretation. Jurnal Sumber Daya Geologi, 22(2), 101-113.

Prasetyadi, C., Soesilo, J., \& Tampubolon, A. P. (2016). Geologi dan Geokimia Batuan Beku Daerah Cawet dan Sekitarmya, Kecamatan Watukumpul, Kabupaten Pemalang, Provinsi Jawa Tengah. Skripsi, Universitas Pembangunan Nasional "Veteran" Yogyakarta.

Van Bemmelen, R. W. (1949). The Geology of Indonesia, Vol. IA, General Geology of Indonesia and Adjacent Archipelagoes, Second Edition. The Hague, Netherlands, p. 732. 


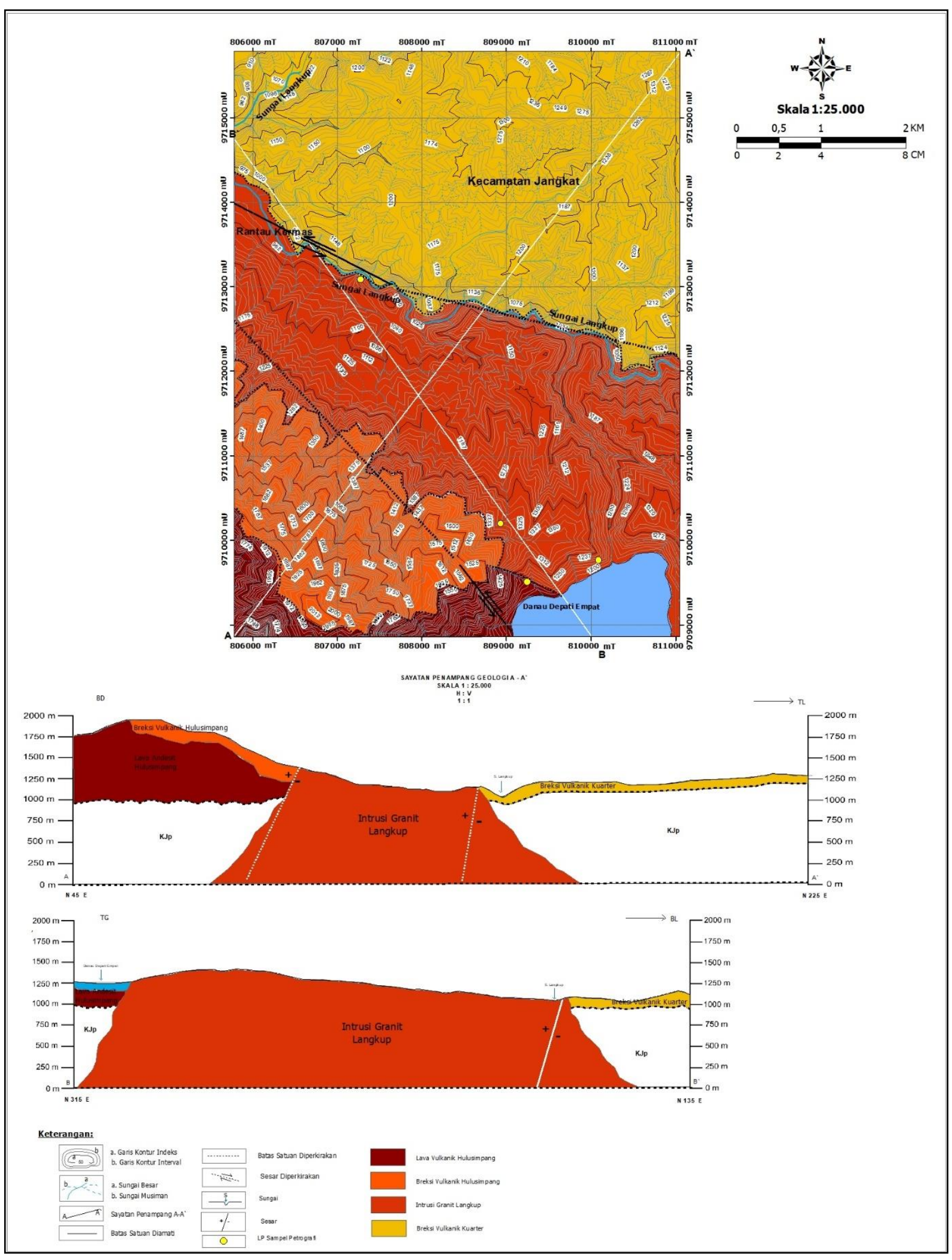

Lampiran Gambar 1. Peta Geologi Daerah Penelitian. 